\title{
EFFECT OF THE LOCATION OF A GASFLOW CONTROL ELEMENT IN AN EJECTOR UNIT ONTHE FLOW PATTERN
}

\author{
Institute of Technical Mechanics \\ of the National Academy of Sciences of U kraine and the State Space Agency of U kraine, \\ 15 Leshko-Popel St., Dnipro 49005, U kraine; e-mail: ai2325434@ gmail.com
}

This article is devoted to a numerical simulation of the flow in a jet mill ejector equipped with a gas flow control element. This element is a channel wherefrom an additional gas flow enters the accelerating tube of the ejector. The gas flows in the mill ejector are controlled using the energy of additional gas flows, thus increasing the velocity of the main flow at the outlet of the ejector accelerating tube and producing a protective layer around the tube walls to prevent their wear. At the same time, there is no substantiation for the choice of optimal control parameters, a methodology, or scientific methods for gas flow control in the ejector channels. The purpose of this work is to investigate the effect of the location of the gas flow control element on gas-dynamic ejector performance and the flow pattern in the ejector channels. A numerical study was carried out using the Ansys Fluent software package and the SST k- $\omega$ turbulence model. In the course of the study, the pressure of the additional gas flow and the distance from the accelerating tube inlet to the energy carrier supply channel were varied. The angle of the additional gas flow was $20^{\circ}$. The numerical simulation gave flow patterns in the ejector as a function of the location of the gas flow control element. Streamlines of the additional gas flow were constructed. The article presents the average flow velocity at the accelerating tube outlet and the energy carrier flow rate as a function of the pressure of the additional flow of the energy carrier and the location of the gas flow control element and the maximum values of the average outlet velocity for given pressure ranges. The article substantiates the choice of the gas flow control parameters that maximize the velocity of the mixed flow at the accelerating tube outlet at a minimum gas flow rate. The results may be used in improving material processing technologies.

Keywords control elements, ejector unit, numerical simulation, additional gas flow.

1. Nikulin O. F., Titenko O. M. Mathematical model of two-phase flow in an accelerator channel. Proceedings of the National Aviation University. 2010. V. 42. No.1. Pp. 65-69. (in Ukrainian). https://doi.org/10.18372/2306-1472.42.1814

2. Shushin N. A. Gas ejector with a tangential injection into the mixing chamber. Uchenye Zapiski TsAGI. 2010. V. XLI. No.3. Pp. 69-81. (in Russian).

https://doi.org/10.1615/TsAGISciJ.v41.i3.60

3. Sheveova H. M., Tynyna S. V. Ways of a two-phase flow control in the jet mill ejector channels. Geoteh. Meh. 2019. No. 144. Pp. 190-198. (in Russian).

https://doi.org/10.15407/geotm2019.144.190

4. Huang B., Chang J., Wang C., Petrenko V. A 1-D analysis of ejector performance. Int. J. Refrig. 1999. V. 22. No. 5. Pp. 354-364.

https://doi.org/10.1016/S0140-7007(99)00004-3

5. Kong F., Kim H. Analytical and computational studies on the performance of a two-stage ejector diffuser system. Int. J. Heat Mass Transf. 2015. V. 85. Pp. 71-87.

https://doi.org/10.1016/j.ijheatmasstransfer.2015.01.117

6. Gagan J., Smierciew K., Butrymowicz D., Karwacki J. Comparative study of turbulence models in application to gas ejectors. Int. J. Therm. Sci. 2014. V. 78. Pp. 9-15.

https://doi.org/10.1016/j.ijthermalsci.2013.11.009

7. Garc a del Valle J., Sierra-Pallares J., Garcia Carrascal P., Castro Ruiz F. An experimental and computational study of the flow pattern in a refrigerant ejector. Validation of turbulence models and real-gas effects. Appl. Therm. Eng. 2015. V. 89. Pp. 795-811.

https://doi.org/10.1016/..applthermaleng.2015.06.064

8. Croquer S., Poncet S., Aidoun Z. Turbulence modeling of a single-phase R134a supersonic ejector. Part 1: Numerical benchmark. Int. J. Refrig. 2016. V. 61. Pp. 140-152.

https://doi.org/10.1016/j.jirefrig.2015.07.030 
9.Croquer S., Poncet S, Aidoun Z. Turbulence modeling of a single-phase R134a supersonic ejector. Part 2: Local flow structure and exergy analysis. Int. J. Refrig. 2016. V. 61. Pp. 153-165.

https://doi.org/10.1016/j.jirefrig.2015.07.029

10.Mazzelli F., Little A.B., Garimella S., Bartosiewicz Y. Computational and experimental analysis of supersonic air ejector: Turbulence modeling and assessment of 3D effects. Int. J. Heat Fluid Flow. 2015. V. 56. Pp. 305-316

https://doi.org/10.1016/j.ijheatfluidflow.2015.08.003

11. Besagni G., Inzoli F. Computational fluid-dynamics modeling of supersonic ejectors: screening of turbulence modeling approaches. Applied Thermal Engineering. 2017. V. 117. Pp. 122-144.

https://doi.org/10.1016/j.applthermaleng.2017.02.011

12. Menter F. R. Two-equation eddy-viscosity turbulence models for engineering application. AIAA Journal. 1994. V. 32. No. 8. Pp. 1598-1605.

https://doi.org/10.2514/3.12149

13. Fedorova N. N., Valger S. A., Danilov M. N., Zakharova Yu. V. Basics of Work in ANSYS 17. DMK Press, 2017. 210 pp. (in Russian).

14. Wilcox D.C. Turbulence Modeling for CFD. Griffin Printing, 1993. 460 pp.

15. Vallander S. V. Lectures on Hydroaeromechanics. Leningrad: Leningrad University, 1978. 312 pp. (in Russian).

16. ANSYS Fluent Theory Guide. Release 2019 R1. ANSYS, Inc. 2019. 922 pp.

Received on September 7, 2020, in final form on September 28, 2020 